\title{
POTENCY OF DIFFERENT SEAWEEDS AS DIETS FOR DEVELOPING ABALONE $(H$. squamata) CULTURE IN NUSA PENIDA ISLAND, BALI
}

\author{
Tri Heru Prihadi ${ }^{1}$, Rasidi $^{2}$, Idil Ardi ${ }^{3}$, Ani Widiyati $^{1}$ and Dwi Budi Wiyanto ${ }^{4}$ \\ ${ }^{1}$ Research Institute for freswater Aquacultuire and Fisheries Extension, Jl. Sempur 1 Bogor, \\ Indonesia; ${ }^{2}$ Research Center for Fisheries, Jl. Ragunan 20 Pasar Minggu South Jakarta, Indonesia; \\ ${ }^{3}$ Institute for Research of Ornamental Fish Aquaculture, Depok West Java, Indonesia; ${ }^{4}$ Marine and \\ Fisheries Faculty of Udayana University, Denpasar, Bali, Indonesia
}

\begin{abstract}
Nusa Penida island is one of center for seaweed culture in Bali province. Seaweed that cultured is Euchema spinosum and Euchema cottoni spread around coastal. There also found wild seaweed, such as Ulva sp and Gracillaria sp. Abalone (H. squamata) is one of kind Mollusca which high economic value, but abalone cultured is not yet develop in Nusa Penida island, although this island have high potency for developing abalone culture. Abalone culture needs seaweeds as a diet. The abundance of seaweeds as abalon diet is important for developing abalon culture in Nusa Penida Island in the future. The aim of this research was to asses the potency of seaweeds as diet for developing abalone culture in Nusa Penida island. Research was done in Batununggul village, Nusa Penida Island. Experimental design was used Completely Randomized Design (CRD) with 3 treatments and 3 replications. The treatments were used different seaweeds as diet for abalone culture: ( $\mathrm{DG}=$ Diet Gracillaria sp, DS=Diet Spinosum sp. and DU=Diet Ulva sp.). Abalon were cultured for 4 months by feeding the diet at satiation. Data analysis was used analysis varian (Anova) with SPSS. 16. The result showed abalon fed with Gracillaria sp (DG) at $4.73 \mathrm{~g}$ was the highest growth by $4.73 \mathrm{~g}$, followed DU by $3.93 \mathrm{~g}$ and DS by $3.43 \mathrm{~g}$. Meanwhile the abalon shell length fed with Gracillaria sp (DG) was the highest growth by $6.55 \mathrm{~mm}$, followed DU by $5.97 \mathrm{~mm}$ and DS by $5.60 \mathrm{~mm}$. Based on variant analysis showed growth performance (length shell and weight) abalon, all treatments were not significantly different $(\mathrm{P}>0.05)$. The conclusion this research, the three species of seaweed can be used as diet for abalone culture. These seaweeds have same potency as diet for developing abalone culture in Nusa Penida Island
\end{abstract}

Corresponding author: rsdrasidi@gmail.comtriheru_p@yahoo.com 


\section{INTRODUCTION}

Abalone is one kind of mollusca which high economic value, the price depends on size and species, between IDR $300.000-400.000 / \mathrm{kg}$. Abalone production from legal catch was $8.650 \mathrm{mt}$ and illegal $5.300 \mathrm{mt}$ in 2008 [1]. Now on production from catch was decreasing so culture of abalone is needed al least to maintaine production of abalone. In Nusa Penida Island was found abalone in the coastal when low tied many last year. According to local people in Nusa Penida the local name of abalon is Seven Eye Shell. They Could catch the Seven eye Shell easily 10 years ago how ever currently it was difficult to get. This information showed in Nusa Penida area was abalone habitat.

Nusa Penida Island Bali is wellknown as center for seaweed culture in Bali province. They are many kinds of seaweed found in Nusa Penida, such as E.spinosum, E.cottoni and as well found seaweed, Gracillaria sp. and Ulva sp. Because so many kinds of seaweed found in that area and we know that seaweed is also as feed resources for abalone And hopefully developing aquaculture will be easier for development in the future. Therefore, this study tried to assess potency the use of many kind of seaweeds as abalone diet in the Nusa Penida island. Food source selection for abalone is influenced by local conditions and seasons in an area development. Seaweed on Nusa Penida growth in the rocks, nets and pole. Wild seaweed can be found easily in the region at low tide. Gracillaria sp.can be found throughout the year, but for Ulva sp. found in the rainy season.

Food is one of the factors that determine the successfull of abalone aquaculture. According Oktaviany [2] abalone requires macro algae such as seaweed which used as an energy source for growth and survival. Gracillaria sp. and Ulva sp. can be use as food for abalone culture [3]. Ungson [4] also reported have been used seaweed Sargassum sp. as abalone food. The aim this research was to know the influence of seaweed as food to abalon growth culture in Nusa Penida Island.

\section{MATERIALS AND METHODS}

Research was conducted in the village Batununggul, Nusa Penida island, Klungkung regency, province Bali (Figure1). Location area of the research was in coastal area with sandy and rocky bottom texture, this location usually was used for seaweed culture. Water depth level was about $0.5-1 \mathrm{~m}$ at the lowest tide some time depends on tidal. Following the conditions existing land abalone culture methods are applied using off-bottom technology. Abalone cultured were used basket containers made from polyethylene, with height of 80 $\mathrm{cm}$ and diameter of $40 \mathrm{~cm}$. The baskets were placed on the bottom and bound with wooden stakes. 


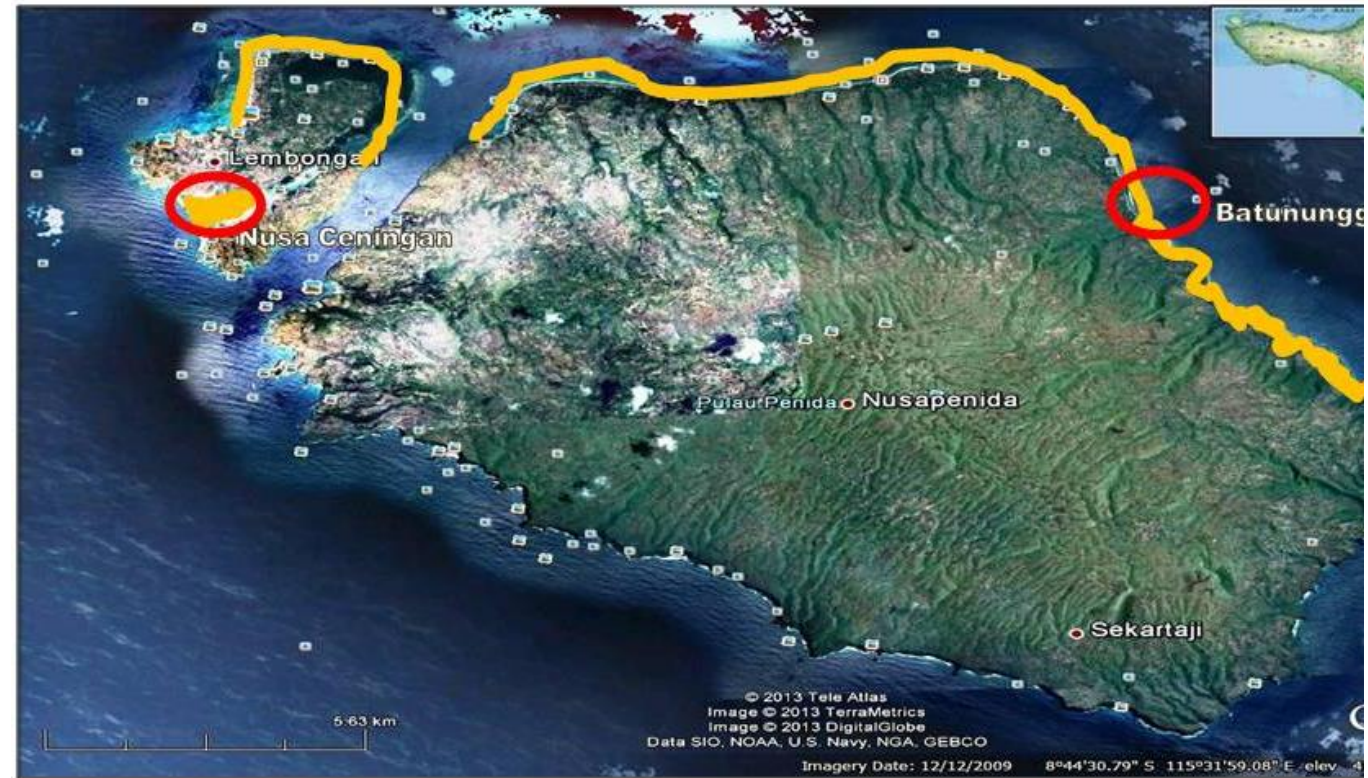

Sumber:petagoogle ea

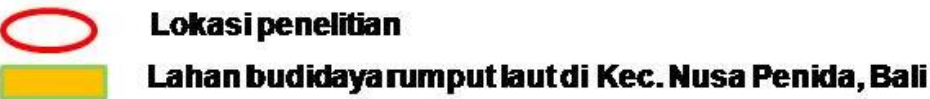

Fig 1. Research location in Batununggul village Nusa Penida Island.

Abalone (Haliotis squamata) were carried out from the Institute for Research and Development of Marine Aquaculture Gondol, North Bali. The research was conducted with stocking density of 100 pcs/basket. The research design was used a Completely Randomized Design (CRD) with 3 treatments $x 3$ replicates. The abalone was fed different seaweed, as treatments. there are (DG) Diet Gracillaria, (DS) Diet Spinosum and (DU) Diet Ulva. Feeding rate used $15 \%$ of the biomass abalone were given every 3 days. According Ungson [4], measurement of shell length and width were done every 15 days using a caliper and weight used a digital scale with a precision of $0.01 \mathrm{~g}$. Measuring the shell length, width, and weight of abalone by random sampling, the number of abalone are measured by $20 \mathrm{pcs} / \mathrm{basket}$.

Length and weight of abalone were used to calculate an absolute growth, Daily Increasing of body weight $(\mathrm{DIBW})=(\mathrm{Wt}-\mathrm{W} 0) /$ time length, growth rate of shell in length $=\mathrm{mm}$, Daily increasing of shell length $(\mathrm{DISL})=\left(\mathrm{Lt}-\mathrm{L}_{0}\right) / \mathrm{t}$. Where, $\mathrm{W}_{0}=$ initial average weight $(\mathrm{g}), \mathrm{W}_{\mathrm{t}}=$ average weight in the end of study $(\mathrm{g}), \mathrm{L}_{0}=$ initial shell length, $\mathrm{L}_{\mathrm{t}}=$ length of the shell the end of study, $t=$ long time culture. Data were analyzed using ANOVA test if there is a real difference followed by a further test using SPSS software version 16 . Seaweed and abalone samples were analyzed proximate in the laboratory IPB Bogor, to know the nutritional content. 


\section{RESULT AND DISCUSSION}

\subsection{Seaweed for abalone diet}

Seaweed is a natural food for abalone in the their habitat [5]. We found many kind seaweed culture and wild seaweed in the coastal near experiment location. Seaweed cultured such us E.spinosum dan E. Cottoni, and wild seaweed are Gracilaria sp. and Ulva sp. Wild seaweed growth up in the rock, net, and the other place near location seaweed farming. Gracillaria sp seaweed. and Ulva sp. commonly found growing attached to the net/peg seaweed cultivation.

The research used three kind of seaweed are Gracilaria sp. Ulva sp. and E. spinosum sp. We analyze proximate sample seaweeds to know nutrient content in the laboratorium IPB Bogor. Nutrients content of seaweed are presented in Table 1. Based on Table 1 obtained protein content in seaweed Gracilaria sp is higher than the other seaweeds. According Handy (2006) protein levels vary depending on the species. The protein content of the proximate analysis results in this study is not different from the protein content of sea Gracillaria used in previous studies [3].

In addition to nutrient content in abalone diets need to be considered such as texture and colour. Gracillaria sp and E.spinosum colour is brown while Ulva sp. Is bright green. Culture development of Abalone continuously as sea food should also be considered. Seaweed Gracilaria sp and E.spinosum sp available throughout the year In Nusa Penida, but Ulva sp. availability depending on the season. Ulva sp. usually appear during the rainy season.

Table 1. Proximate analyzed from different seaweeds used on this experiment

\begin{tabular}{|l|c|c|c|c|c|}
\hline \multirow{2}{*}{ Parameters } & \multirow{2}{*}{ Unit } & \multicolumn{3}{c|}{ Species of seaweed } & Technique Analysis \\
\cline { 3 - 6 } & & Gracillaria sp./DG & E. spinosum/DS & UIva sp./DU & \\
\hline Water Content & $\% \mathrm{w} / \mathrm{w}$ & 45.55 & 48.02 & 38.08 & Gravimetry \\
\hline Ash Content & $\% \mathrm{w} / \mathrm{w}$ & & 25.49 & 34.49 & Gravimetry \\
\hline & $\% \mathrm{w} / \mathrm{w}$ & 24.8 & 3.48 & 6.77 & Kjeldhal (Titrimetry) \\
\hline Protein & & 8.01 & 0.14 & 0.19 & Soxhlet \\
\hline Fat & $\% \mathrm{w} / \mathrm{w}$ & 0.1 & 22.49 & 21.3 & $\begin{array}{c}\text { Phenol Sulphate } \\
\text { (spektrometry) }\end{array}$ \\
\hline Carbohydrate & $\% \mathrm{w} / \mathrm{w}$ & 22.56 & 2.76 & 3.71 & Gravimetry \\
\hline Crude Fiber & $\% \mathrm{w} / \mathrm{w}$ & 5.15 & & & \\
\hline
\end{tabular}

Table 1. showed proxymate analyzed from different seaweed used in this experiment. Spinosum looked the highest of water content with $45.55 \% \mathrm{w} / \mathrm{w}$, while Ulva was the lowest water containt with $38.08 \% \mathrm{w} / \mathrm{w}$. The highest 0 f Ash was Ulva with 34.49. the highest of protein, carbohydrat and crude fiber was belonging of Gacilaria with $8.01 ; 22.56$ and 5.15 $\% \mathrm{w} / \mathrm{w}$, however gracilaria has the lowest in fat with $0.1 \% \mathrm{w} / \mathrm{w}$. Data in detail of proxymate analyzed could be read in table 1 .

\subsection{Abalone Growth}

Feed or Diets is one factor that affect growth of abalone, biomass growth is very important in the cultivation of abalone [6]. Based on Figure 2 and 3, shows absolute growth (shell length and weight) obtained in abalone with treatment DG is the higher followed by DU and DS is the lowest. Based on the results of analysis variance absolte growth shows 
that treatment give effect in growth (shell length and weight) of abalone did not differ significantly between all treatments $(\mathrm{P}>0.05)$.

Three species of seaweed which are used as food or diets for abalone culture as Gracilaria sp, E.Spinosum and Ulva sp. Gracillaria sp. had growth response as the highest compare to other treatments (Figure 2). This happens was caused by nutrient content of Gracillaria sp. is the highest compared to others (Table 1). Abalone need nutrient such us protein, carbohydrat, fat and the other for their growth. Protein content in Gracillaria sp. is the higher than the other seaweed. Protein are important nutrient for growth abalone [7].

The result in this experiment statistically produced growth abalone (shell length and weight) did not differ significantly among treatment. These results experiment indicate three different seaweed are equally can be uses as a source of food for abalon culture. Compare than previous studies, Gracillaria sp. from the sea was used as food for abalone resulted growth is lowest compared Ulva sp. and Gracilaria sp. from brachiswater in the laboratory experiment [3]. Different seaweed for abalone fed increased growth, it can be seen from the length and weight of abalone shells during the study. Daily increase body weight and shell length of abalone all treatments are presented in Table 1.

Table 2. Size, Daily Increasing of Body Weight (DIBW) and Daily Increasing of Shell Length of abalone during experiment..

\begin{tabular}{|c|c|c|c|c|r|r|}
\hline \multirow{2}{*}{ Treatment } & \multicolumn{2}{|c|}{ Initial experiment } & \multicolumn{2}{c|}{ End experiment } & DIBW & DISL \\
\cline { 2 - 7 } & $\begin{array}{c}\text { Weight } \\
(\mathrm{g})\end{array}$ & $\begin{array}{c}\text { Shell Length } \\
(\mathrm{mm})\end{array}$ & $\begin{array}{c}\text { Weight } \\
(\mathrm{g})\end{array}$ & $\begin{array}{c}\text { Shell Length } \\
(\mathrm{mm})\end{array}$ & (g/day) & mm/day \\
\hline DG & 10.91 & 40.32 & 15.64 & 46.87 & 0.045 & 0.063 \\
\hline DS & 10.73 & 40.50 & 14.22 & 46.10 & 0.034 & 0.054 \\
\hline DU & 10.22 & 38.90 & 14.19 & 44.87 & 0.038 & 0.057 \\
\hline
\end{tabular}

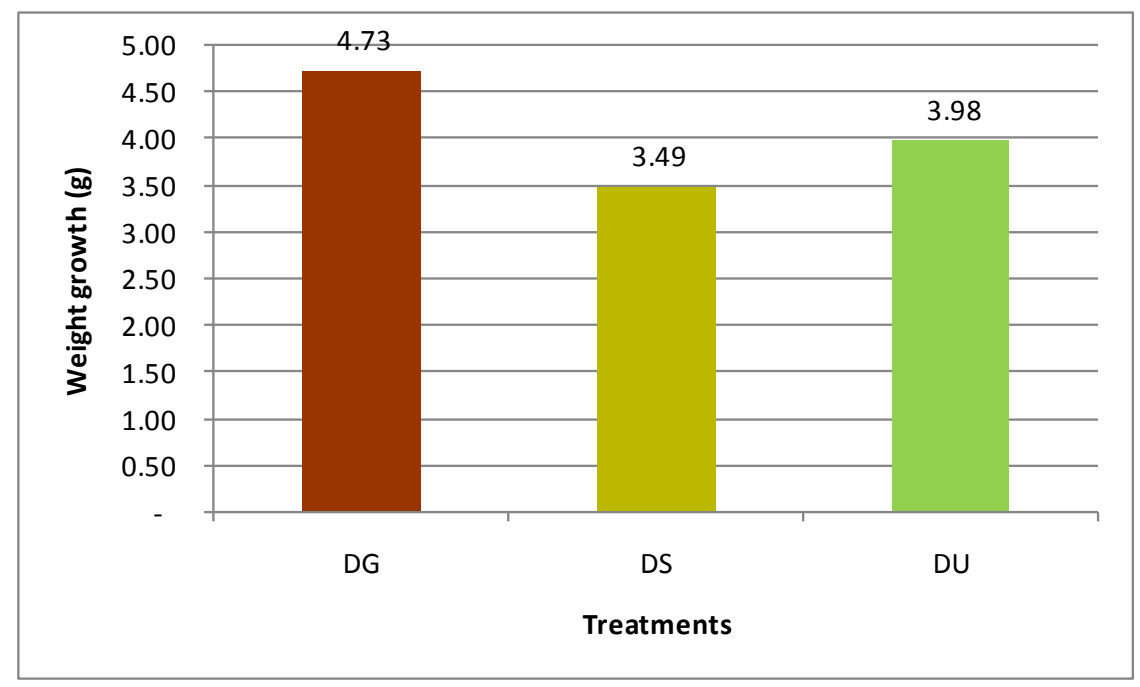

Fig2. Total growth (weight) of abalone among treatment during 4 months rearing $(\mathrm{DG}=$ Diet Gracilaria, DS $=$ Diet Diet Spinosum and DU $=$ Diet Ulva) 


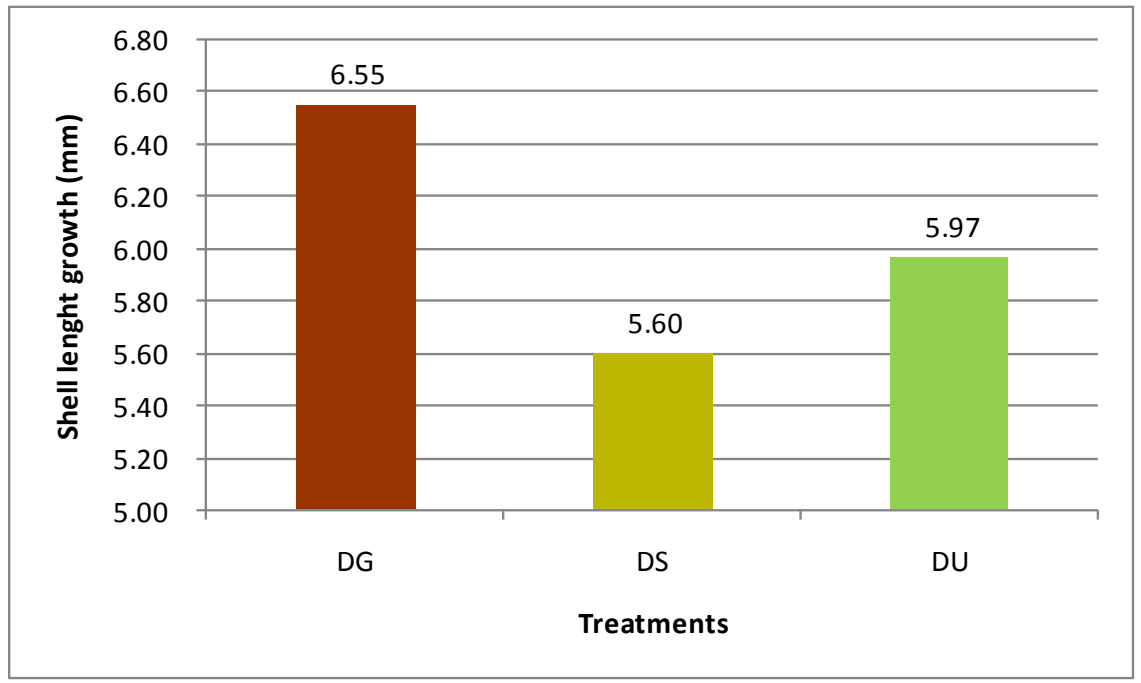

Fig 3. Total growth (shell length) of abalone among treatment during 4 months rearing $(\mathrm{DG}=\mathrm{Diet}$ Gracilaria, DS = Diet Spinosum and DU = Diet Ulva)

Abalone were spread has increased shell length during cultivation. According by Figure 3, abalone shell length in DG is higher than the other treatments. Seaweed Gracillaria sp. have high nutrition so abalone shell length also increased like their weight. This result experiment is higher than result previous studied [3].

Abalone shell is formed from mineral and calcium contained in the waters. Shell color also is influenced by the food, abalone fed seaweed Ulva color will seen bright green. Likewise abalone fed Gracillaria and spinosum seaweed would brownish colour. These results are consistent with studies using laboratory scale Gracillaria marine origin and Ulva [3]. Yong $\mathrm{Ju}$, et al., [8] also reported the use of brown seaweed and produce red abalone with shell color matches the color of seaweed are given.

The results of the proximate analysis of abalone at the end of the experiment are presented in Table 3. Base on Table 3 showed protein content abalone with food seaweed Ulva (DU) is highest followed by treatment abalone food Gracilaria sp. (DG) and the lowest in abalon with diet seaweed Spinosum sp. (DS). It is inversely proportional to the protein content of seaweed that are used as food abalone. This condition is the same as the results of research Ungson [4] reported protein content two kinds of seaweed Sargassum sp is higher, it used food for abalone but have growth did not differ significantly. In addition to nutrient content, seaweed texture also affect the outcome of the study, the texture of Ulva sp. is softer than Gracillaria sp. and Spinosum sp., so more easily digested by the abalone. 
Table 3. The proximate analysis of abalone at the end of research

\begin{tabular}{|l|c|c|c|c|c|}
\hline \multirow{2}{*}{ Parameters } & \multirow{2}{*}{ Unit } & \multicolumn{3}{|c|}{ Treatment } & \\
\cline { 3 - 5 } & & DG/Gracillaria sp. & DS/Spinosum sp. & DU/UIva sp. & Technique Analysis \\
\hline Water Content & $\% \mathrm{w} / \mathrm{w}$ & 23.15 & 29.26 & 24.58 & Gravimetry \\
\hline Ash Content & $\% \mathrm{w} / \mathrm{w}$ & & 9.7 & 8.97 & Gravimetry \\
\hline & & 8.99 & 33.22 & 46.63 & Kjeldhal (Titrimetry) \\
\hline Protein & $\% \mathrm{w} / \mathrm{w}$ & & 2.19 & 1.85 & Soxhlet \\
\hline Fat & $\% \mathrm{w} / \mathrm{w}$ & 3 & 25.36 & 17.41 & $\begin{array}{c}\text { Phenol Sulphate } \\
\text { (spektrometry) }\end{array}$ \\
\hline Carbohydrate & $\% \mathrm{w} / \mathrm{w}$ & 22.14 & 0.38 & 0.45 & Gravimetry \\
\hline Crude Fiber & $\% \mathrm{w} / \mathrm{w}$ & 0.3 & & &
\end{tabular}

Table 3 showed proximate analyisis (water content, ass content, protein, fat, carbohydrate and crude fiber) of abalone which were feed from three species was not significant different.

\section{CONCLUSIONS}

Three species of seaweed Gracillaria sp, E. spinosum and Ulva sp. which are used as feed for abalone produced the same growth respon among treatments. Based on these data, three species of seaweed can be used as feed in abalone culture in Nusa Penida Island Bali.

The authors would like to thank Mr I Nyoman Landep, The Dean of Faculty of Fisheries and Marine, Udayana University for the collaboration and cooperated research. This research were supported by government fund budget from Research Center for Aquaculture Jakarta. Indonesia

\section{Refference}

1 Cook P.A.,\& H. R Gordon. 2010. World Abalon Supply, Markets, and Pricing. Journal Shellfish Research 29 (3): 569-571.

2 Oktaviany, M.J. 2007. Beberapa catatan tentang aspek biologi dan perikanan abalon. Oseana XXXII (4): $9 \mathrm{hlm}$.

3 Susanto, B., I. Rusdi \& I.N. Adiasmara Giri. 2012. Optimalisasi pemeliharaan yuwana abalon $(H$. squamata) dengan kepadatan dan jenis pakan yang berbeda. Jurnal Riset Akuakultur 7(1): $21-31$.

4 Ungson, J.R. 2003. Fooding of Abalon Juveniles with Two Species of Sargassum (Sargassum cristaefolium and Sargassum polycystum). Philippine Journal of Science 132 (1): 33-38

5 Body, A. G. C., 1987. Abalone Culture in Japan. Marine Fisheries Review 49(4): 75-76. 
6 Francis T.L. 2008. The Effects of Differences in Fooding Regime and of Export Simulations on the Growth of the abalon Haliotis midae Linnaeus. Thesis. University of the Western Cape. South Africa.104 hal

7 Fleming, A.E.,Van Barneveldt, R.J \& Hone, P.W. 1996. The development of artificial diets for abalone: A review and future directions. Aquaculture, 140: 5-53.

8 Yong Ju, Z., Dong-Fang Deng, W. Dominy, C. Viljoen, P. Hutchinson. 2013. Remarkable Affect of Diets on Abalon Meat Nutrient Composition and Shell

Pigmentation. http://www.ctsa.org/files/publications/AbalonDiets Ju OI.pdf. dowlod at 24 Desember 2013. 